Bartosz Twarowski

\title{
DZIAŁANIA BANKU CENTRALNEGO NORWEGII W CZASIE KRYZYSU GOSPODARCZEGO 2007+
}

\section{Wprowadzenie}

Kryzys finansowy zapoczątkowany w 2007 roku na rynku kredytów subprime w Stanach Zjednoczonych po objęciu gospodarki realnej w 2008 roku dotknął także gospodarki państw europejskich. W Norwegii miał on jednak relatywnie łagodny przebieg. Celem opracowania jest przedstawienie pozytywnego wpływu makroekonomicznego zarządzania na przebieg kryzysu w Norwegii. Było to możliwe dzięki silnej gospodarce państwa zasilanej pieniędzmi z sektora naftowego, bardzo niskiemu bezrobociu i nadwyżce finansowej. Silna gospodarka zasilana pieniędzmi z sektora naftowego, dobra sytuacja makroekonomiczna: bardzo niskie bezrobocie i nadwyżka finansowa, a także wysoka jakość makroekonomicznego zarządzania sprawiły, że instytucje państwa skutecznie zminimalizowały dotychczasowe skutki kryzysu. Większość czynników determinujących stabilność makroekonomiczną w Norwegii wynika ze strukturalnych cech norweskiej gospodarki. Mimo to działania rządu i banku centralnego miały bardzo duży udział w ochronie gospodarki. Celem opracowania jest przedstawienie kluczowych działań norweskiego banku centralnego w zakresie polityki monetarnej i zarządzania funduszem naftowym, a także ukazanie wpływu poszczególnych decyzji na utrzymanie stabilności gospodarczej w państwie. Ponieważ Bank Norwegii oraz jego działania nie są zagadnieniem powszechnie znanym, autor prezentuje również podstawowe kompetencje banku w zakresie polityki makroekonomicznej i kwestie dotyczące zarządzania tą instytucją. Analiza działań instytucji norweskich podzielona została na dwa okresy: lata 2008-2010, czyli czas najgłębszego kryzysu, kiedy działania antycykliczne cechowały się największą dynamiką, oraz lata 2010-2012, gdy ustabilizowano sytuację gospodarczą. 


\section{Norges Bank i jego kompetencje}

Norweskim bankiem centralnym jest Norges Bank (Bank Norwegii). Jego kompetencje uregulowane są $\mathrm{w}$ wielu norweskich aktach prawnych $\mathrm{w}$ randze ustaw przyjmowanych przez jednoizbowy norweski parlament (Storting) i rozporządzeniach, które są wydawane przez odpowiedniego ministra.

Podstawowym dokumentem regulującym kompetencje Banku Norwegii jest ustawa o Banku Norwegii (Sentralbankloven). Na jej mocy bank ten jest organem wykonawczym i doradczym w zakresie norweskiej polityki monetarnej, kredytowej i kursu walutowego. Odpowiada on za emisje banknotów i monet (korony norweskiej = 100 øre), promocję efektywnego systemu płatniczego $\mathrm{w}$ wymiarze krajowym i międzynarodowym, a także monitoring rynków: kredytowego, pieniężnego i walutowego ${ }^{1}$. Ustawa nakłada na bank obowiązek prowadzenia swojej działalności w zgodzie z założeniami polityki gospodarczej rządu i międzynarodowymi zobowiązaniami państwa.

Szczegółowe prerogatywy Banku Norwegii w ustawie o Banku Norwegii dotyczą kilku obszarów: środków płatności, rynku kredytowego, międzynarodowego rynku walutowego, polityki informacyjnej i budżetu. W zakresie środków płatności Bank Norwegii jest jedynym podmiotem emitującym banknoty i monety, decydującym o ich liczbie, wyglądzie i nominałach. Emisja banknotów jubileuszowych zależna jest od decyzji króla. Na rynku kredytowym Bank Norwegii pełni kilka zadań.

- Jest bankierem rządu. Przeprowadza transakcje dla rządu Norwegii.

- Jest kredytodawcą rządu.

- Jest kredytodawcą banków. Może udzielać pożyczek bankom komercyjnym i oszczędnościowym. Decyduje o wysokości kredytów, oprocentowaniu, warunkach spłaty i stopie dyskontowej.

- Jest depozytariuszem banków. Przyjmuje depozyty od banków komercyjnych.

- Nabywa i sprzedaje papiery wartościowe. Może kupować i sprzedawać instrumenty dłużne emitowane przez państwo i inne łatwo zbywalne instrumenty dłużne, a także emitować własne instrumenty dłużne.

- W szczególnych wypadkach kredytuje i jest depozytariuszem dla pozabankowych podmiotów sektora finansowego.

$\mathrm{Na}$ międzynarodowym rynku walutowym bank prowadzi notowania kursów walutowych i zarządza oficjalnymi rezerwami dewizowymi. Inwestuje rezerwy w celu utrzymania ustalonej polityki kursowej. Przeprowadza transakcje walutowe

1 „Lov om Norges Bank og pengevesenet mv. (sentralbankloven)“, § 1. Norges Banks formål og virkeområde. 
dla rządu, często wypełniając zobowiązania państwa wynikające z członkostwa w Międzynarodowym Funduszu Walutowym. Ponadto bank może zawierać umowy dotyczące depozytów, kredytów i gwarancji z zagranicznymi bankami centralnymi, innymi instytucjami kredytowymi, międzynarodowymi organizacjami gospodarczymi (po zgodzie króla). W zakresie polityki informacyjnej Bank Norwegii ma zbierać dane od podmiotów w sektorze finansowym na temat ich działalności, finansowania, rozliczeń, transakcji i rachunków klientów i inne niezbędne dane do wykonywania swoich zadań (np. prowadzenie statystyk czy informowanie ciał kontrolnych). Bank Norwegii musi również przygotowywać projekt budżetu na kolejny nadchodzący rok, który po zatwierdzeniu przez radę nadzorczą przekazywany jest do ministerstwa. Ponadto przygotowuje sprawozdanie finansowe za każdy rok przyjmowane przez radę nadzorczą.

Szczegółowe kompetencje Banku Norwegii w zakresie polityki monetarnej zawarte są w rozporządzeniu o polityce monetarnej z 29 marca 2001 roku (nor. Forskrift om pengepolitikken). Określa ono cel polityki monetarnej w postaci troski o niską i stabilną inflację. Cel inflacyjny ustanowiony jest na poziomie $2,5 \%$. Oznacza to, że bank centralny powinien dążyć do stabilnego w czasie wzrostu cen dóbr konsumpcyjnych według wskaźnika CPI na poziomie 2,5\%. Dla porównania w Szwecji celem jest inflacja na poziomie $2 \%$, a w Danii kurs walutowy powiązany z euro z 2,25\% pasmem wahań.

Zgodnie z regulacją bank centralny nie interesuje się bezpośrednimi skutkami zmian stóp procentowych, podatków, akcyzy i zakłóceń rynkowych dla kształtowania się cen. Decyzje dotyczące wysokości stóp procentowych i ważnych zmian w stosowaniu instrumentów polityki monetarnej podejmowane są na zebraniach zarządu, które odbywają się co sześć tygodni. Decyzje podejmowane są na podstawie analiz i strategii zawartych w raportach polityki monetarnej banku oraz zmian cen, kosztów i sytuacji na rynku pieniężnym i kursowym. Na podstawie analiz i dyskusji zarząd ocenia konsekwencje zmian, bądź braku zmian stóp procentowych i przyjmuje strategię polityki pieniężnej, w tym strategie alternatywne. Na podstawie tego przyjmuje się strategię polityki pieniężnej, w tym strategie alternatywne. Decyzja w sprawie przyjęcia strategii polityki dokonywana jest $\mathrm{w}$ tym samym dniu, gdy jest on publikowany. Przyjęta strategia obowiązuje do czasu publikacji kolejnego raportu.

Działania operacyjne banku prowadzone są w dwóch obszarach: zadań banku centralnego (nor. Sentralbankvirksomheten) oraz zarządzania inwestycjami (Kapitalforvalting, realizowane przez Norges Bank Investment Management). Podział ten wynika ze szczególnych kompetencji banku centralnego w zakresie zarządzania Globalnym Rządowym Funduszem Emerytalnym (Statens pensjonsfond utland/Government Pension Fund - Global). 


\section{Zarządzanie funduszem naftowym}

Norges Bank zarządza funduszem naftowym poprzez departament ds. inwestycji (Norges Bank Investment Management). Sam fundusz powstał w roku 1996 i ma na celu chronienie gospodarki narodowej przed negatywnymi konsekwencjami dynamicznego rozwoju sektora wydobywczego. W odróżnieniu od większości państw eksporterów ropy naftowej i gazu, których budżety narodowe uzależnione są od wpływów ze sprzedaży ropy i gazu, Norwegia chroni rodzimą gospodarkę i odracza konsumpcję przychodów z sektora naftowego. Globalny Rządowy Fundusz Emerytalny inwestuje posiadane środki na zagranicznych rynkach finansowych, przez co pieniądze te w większości nie trafiają do budżetu rządu i nie zasilają gospodarki narodowej. Zgodnie z rozporządzeniem Ministra Finansów Królestwa Norwegii ${ }^{2}$ Norges Bank jest instytucją odpowiadającą za obrót aktywami i maksymalizacje stopy zwroty z inwestycji. Polityka inwestycyjna w tym zakresie jest w pełni niezależna od ministerstwa finansów.

\section{Rysunek 1. Cash flow netto rządu Norwegii i jego składowe związane z zarządzaniem i bezpośrednim zaangażowaniem w sektor naftowy w latach 1972-2010 (w mld koron)}

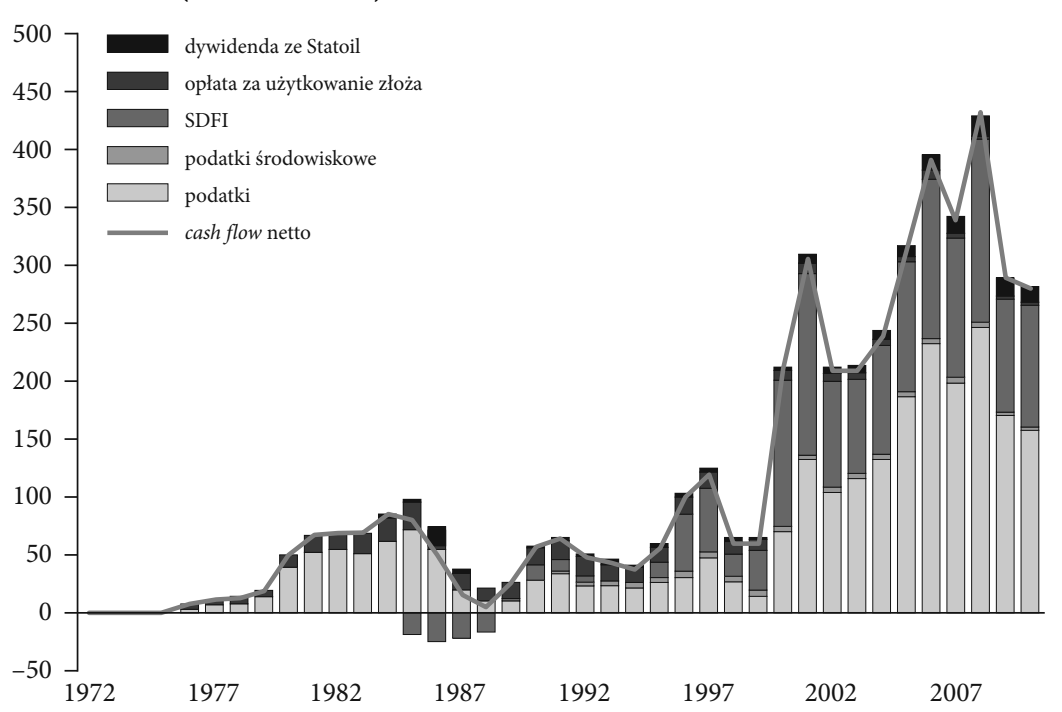

Źródło: Facts 2012. The Norwegian Petroleum Sector, red. J.Ø. Hansen, Ministry of Petroleum and Energy of Norway, Oslo 2012, s. 22, http://npd.no/Global/Engelsk/3-Publications/Facts/ Facts2012/Facts_2012_web.pdf (12.08.2012).

2 Fastsatt av Finansdepartementet, 8. november 2010 med hjemmel i lov 21. desember 2005 nr. 123 om Statens pensjonsfond, $\$ 2$ annet ledd og $\$ 7$, http://www.nbim.no/no/About-us/governance-model/ management-mandate/ (19.08.2012). 
Środki przekazywane są następnie do Globalnego Rządowego Funduszu Emerytalnego, który jest odpowiedzialny za ich gromadzenie i zarządzanie. Jak pokazuje rysunek 1, główne składowe przychodów państwa wynikają z podatków bezpośrednich oraz bezpośredniego zaangażowania w wydobycie (SDFI). W 2011 roku wartość transferów do funduszu wyniosła około 271 mld koron norweskich (około $153 \mathrm{mld}$ zł, według kursu historycznego NBP w dniu 31 grudnia 2011 roku). Natomiast wartość rynkowa wszystkich aktywów posiadanych przez fundusz na koniec roku 2011 przekroczyła 3312 mld koron (około 1,7 bln zl, według kursu historycznego NBP w dniu 31 grudnia 2011) $)^{3}$. Dynamika wzrostu aktywów funduszu przedstawiona jest na rysunku 2. Ich wartość w 2011 roku wyniosła około 120\% rocznego PKB Norwegii. Rysunek pokazuje, że załamanie gospodarcze z roku 2007 nie spowodowało załamania długookresowej tendencji wzrostowej wartości rynkowej aktywów funduszu, która wydaje się być niezagrożona w najbliższym czasie.

\section{Rysunek 2. Dynamika wzrostu aktywów Globalnego Rządowego} Funduszu Emerytalnego w latach 1996-2011

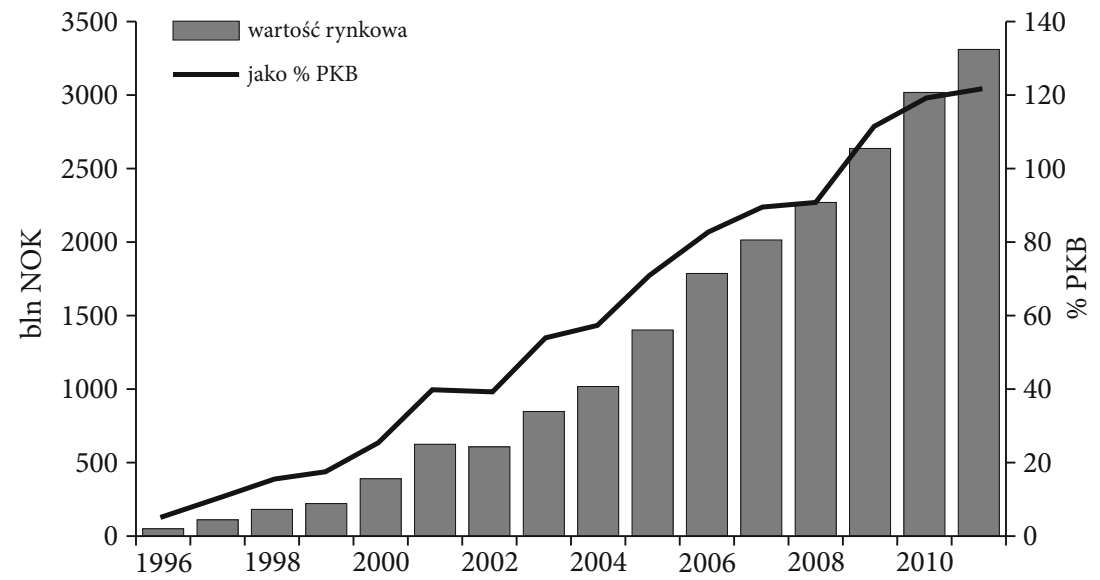

Źródło: Facts 2012. The Norwegian Petroleum Sector, op.cit.

Choć Globalny Rządowy Fundusz Emerytalny powstał w celu wspierania publicznego systemu emerytalnego w warunkach starzejącego się społeczeństwa, obecnie nie przekazuje bezpośrednio żadnych środków na cele emerytalne, ma natomiast odprowadzać do budżetu skarbu państwa składkę w wysokości nieprzekraczającej $4 \%$ z zysków inwestycyjnych. Działania inwestycyjne funduszu prowadzone są na

3 Facts 2012. The Norwegian Petroleum Sector, red. J.Ø. Hansen, Ministry of Petroleum and Energy of Norway, s. 20, http://npd.no/Global/Engelsk/3-Publications/Facts/Facts2012/ Facts_2012_web.pdf (18.08.2012). 
rynkach akcji, obligacji i nieruchomości według następującego podziału geograficznego: maksymalnie 50\% środków alokowanych jest na rynkach europejskich, 35\% w Ameryce Północnej, Afryce i Bliskim Wschodzie, a 15\% w Azji i Oceanii. W rynek akcji inwestuje się nie więcej niż 60\%, 30-40\% w papiery wartościowe o stałym dochodzie, a $5 \%$ w nieruchomości. Fundusz może posiadać nie więcej niż $10 \%$ udziałów w spółkach notowanych na giełdzie4.

Na rynku akcji Globalny Rządowy Fundusz Emerytalny inwestuje w sposób bardzo zdywersyfikowany w różne rynki i sektory, zależnie od wybranej strategii (wśród których dominuje strategia indeksowania oraz strategie sektorowe, kapitałowe, zewnętrzne) $)^{5}$. Największe środki fundusz przeznaczył na inwestycje $\mathrm{w}$ akcje dużych międzynarodowych koncernów, notowanych na największych indeksach giełdowych w swoich państwach, takich jak: Shell, Nestle czy HSBC. Biorąc z kolei pod uwagę inwestycje w obligacje, portfolio funduszu składa się głównie z obligacji państwowych, wśród których największe pakiety stanowią obligacje Stanów Zjednoczonych, Wielkiej Brytanii oraz Francji ${ }^{6}$. Na uwagę zasługuje duży udział obligacji hiszpańskich o wysokiej rentowności związanej z pogarszającą się sytuacją gospodarczą tego kraju. Fundusz jest też w posiadaniu znacznych ilości obligacji Grecji (ponad 500 mln euro pod koniec roku 20107), jednak straty związane z restrukturyzacją greckiego długu zostały w tym segmencie zrekompensowane z nawiązką dzięki rosnącej rentowności obligacji amerykańskich i brytyjskich ${ }^{8}$.

\section{Instrumenty Banku Norwegii w zakresie polityki pieniężnej}

Podstawowym instrumentem polityki pieniężnej Banku Norwegii jest główna stopa procentowa, czyli stopa procentowa depozytów banków komercyjnych w banku centralnym do określonego limitu, powyżej którego oprocentowanie depozytów jest

${ }^{4}$ Fastsatt av Finansdepartementet, 8. november 2010 med hjemmel i lov 21. desember 2005 nr. 123 om Statens pensjonsfond $₫ 2$ annet ledd og $\$ 7$. Endringer: Endret ved vedtak 21 des $2010 \mathrm{nr}$. 1792, 5 sep $2011 \mathrm{nr} .901$, http://www.nbim.no/en/About-us/governance-model/management-mandate/

5 Szczegóły: http://www.nbim.no/en/Investments/equity-management/ (20.08.2012).

${ }^{6}$ Government Pension Fund Global Annual Report 2011, Norges Bank Investment Management, Oslo 2012, s. 43, http://www.nbim.no/Global/Reports/2011/Annual\%20report\%202011/Arsrapport_11_ENG_ web.pdf (21.02.2013).

7 Szerzej zobacz: Norges Bank, http://www.norway.gr/News_and_events/Business/Norway-invests-in-Greece/ (01.09.2012).

8 Por. J. Boyd, Greek PSI details hidden from Norway SWF, Investment Europe Website, http:// www.investmenteurope.net/investment-europe/news/2161450/greek-psi-details-hidden-norway-swf, (01.09.2012). 
niższe. Stopa ta dotyczy depozytów a vista (sight deposit rate). Główna stopa procentowa ma przełożenie na poziom krótkookresowych stóp na rynku międzybankowym. Wysokość głównej stopy procentowej jest bezpośrednio powiązana z wysokością stopy procentowej O/N (d-loans). Stopa O/N do 1993 roku była główną stopa procentową w Norwegii, a dziś jest z nią sztywno związana i wyższa o 1 p.p. Główna stopa procentowa oraz oczekiwania związane z jej wysokością mają też duży wpływ na kształtowanie stóp procentowych wkładów bankowych i pożyczek w bankach komercyjnych oraz rentowności obligacji ${ }^{9}$. Oddziaływanie głównej stopy procentowej na gospodarkę, a przede wszystkim na inflację, która jest głównym przedmiotem troski Banku Norwegii, odbywa się za pośrednictwem trzech kanałów: kanału popytowego, kanału kursu walutowego oraz kanału oczekiwań ${ }^{10}$.

Podstawowym kanałem transmisji są konsumpcja i inwestycje. Wpływ zmiany stóp procentowych na inflację następuje z opóźnieniem i ma różną intensywność. W czasie potrzebnym na przełożenie zmiany stóp na gospodarkę inne czynniki mogą wpłynąć na wielkość inflacji i w konsekwencji produkcję. Gdy stopy procentowe spadają, konsumpcja gospodarstw domowych i rządu będzie miała tendencję wzrostową. Będzie to wynikać $z$ nadwyżki pieniędzy powstałej na skutek spadu kosztów obsługi długu i dalszego zadłużania. Sytuacja finansowa przedsiębiorstw poprawia się i następuje wzrost inwestycji. Rosnący popyt prowadzi do wyższej produkcji i wzrostu zatrudnienia. Następuje wzrost płac, a on w połączeniu z wyższymi marżami spowoduje wzrost inflacji. Wpływ zmian stopy procentowej może być wzmocniony, gdyż stopa wpływa również na kurs wymiany korony norweskiej. Gdy stopy procentowe są niższe, więcej ludzi pożycza pieniądze, a mniej akumuluje gotówkę. Niższe stopy procentowe będą zatem prowadzić do deprecjacji korony. Importowane towary zdrożeją, a inflacja będzie rosła. Słabsza korona zwiększy eksport, a przez to poprawi wyniki w sektorze biznesowym. Siła oddziaływania kanału kursowego może być różna zależnie od nastrojów i motywów na rynku walutowym.

Duże znaczenie odgrywa również kanał związany z oczekiwaniami dotyczącymi przyszłej inflacji. Oczekiwania te mają duże znaczenie dla rynku walutowego, mają wpływ na żądania płacowe i pośrednio na ceny. Siła oddziaływania banku centralnego na oczekiwania jest bardzo niewielka i wpływ ten jest trudny do zbadania, natomiast pewne znaczenie może mieć tu zaufanie do celów inflacyjnych banku oraz historyczny poziom inflacji. W warunkach zaufania do polityki pieniężnej oczekiwania inflacyjne będą zbliżone do celu inflacyjnego, co dodatkowo ułatwi jego osiągnięcie.

\footnotetext{
9 Źródło: strona internetowa Banku Norwegii, http://www.norges-bank.no/en/price-stability/ monetary-policy-in-norway/monetary-policy-instruments/ (01.09.2012).

10 Norges Bank Annual Report, Norges Bank, Oslo 2004, s. 17. http://www.norges-bank.no/upload/ import/english/publications/annual_report/2003/ar-2003.pdf (01.09.2012).
} 
Natomiast w warunkach braku zaufania do banku centralnego osiągnięcie celu będzie trudniejsze. Kanał oczekiwań wzmacnia efekty polityki pieniężnej ${ }^{11}$. Poza zmianą głównej stopy procentowej Bank Norwegii może dokonywać interwencji na rynku walutowym mających na celu korygowanie kursu korony. Nie jest to często stosowany instrument polityki monetarnej, gdyż ma charakter krótkookresowy. Jednakże stosuje się go, gdy kanał kursu walutowego może mieć wpływ na nieosiągnięcie celu inflacyjnego, gdy następują krótkookresowe i duże wzrosty wartości korony. Kolejnym instrumentem polityki pieniężnej Banku Norwegii są pożyczkif-loans, tzn. kredyty udzielane bankom komercyjnym pod zastaw papierów wartościowych. Bank oferuje je w stałych cenach i terminach zapadalności od jednego dnia do sześciu miesięcy. Jeden bank może zaciągnąć pożyczkę o wartości nieprzekraczającej $1 \mathrm{mld}$ koron. Bank Norwegii oferuje kredyty f-loans w aukcjach. Gdy kredyty nie zapewnią wystarczającej płynności na rynku, bank ma możliwość dostarczenia płynności poprzez swapy walutowe $\left(f x \operatorname{swaps}^{12}\right)$. Swapy walutowe mają wówczas za zadanie dostarczyć waluty i zasilić w płynność banki komercyjne posiadające nadwyżki aktywów/pasywów w koronach i innych zagranicznych walutach. Dostawy walut obcych za pomocą swapów stosowane są tylko w wyjątkowych okolicznościach.

\section{Analiza działań Banku Norwegii w 2008 roku}

Zgodnie z instrumentami Banku Norwegii podstawowe działania banku w czasie kryzysu na rynkach światowych opierały się głównie na manewrowaniu wysokością głównej stopy procentowej. Kluczowe decyzje w tym zakresie zapadały w roku 2008.

W pierwszej połowie tego roku inflacja w Norwegii miała wyraźną tendencję wzrostową. Zmiany wysokości inflacji w tym czasie w postaci zmian indeksu cen dóbr i usług konsumpcyjnych przedstawia rysunek 3. Jednym z powodów rosnącej inflacji były zawirowania na rynkach zagranicznych, które w dużym stopniu wpływają na sytuację wewnętrzną otwartej i nastawionej na eksport gospodarki norweskiej.

\footnotetext{
11 Ibidem, s. 18.

12 Swap walutowy to umowa, w której dwie strony wymieniają między sobą określoną kwotę waluty na równowartość $\mathrm{w}$ innej walucie, na określony czas. W trakcie trwania transakcji nie ma płatności odsetek. Kurs wymiany na datę zapadalności jest ustalany w oparciu o różnicę oprocentowania tych walut.
} 
Rysunek 3. Wysokość indeksu cen towarów i usług konsumpcyjnych CPI wraz ze wskaźnikami pochodnymi w Norwegii w latach 2004-2012

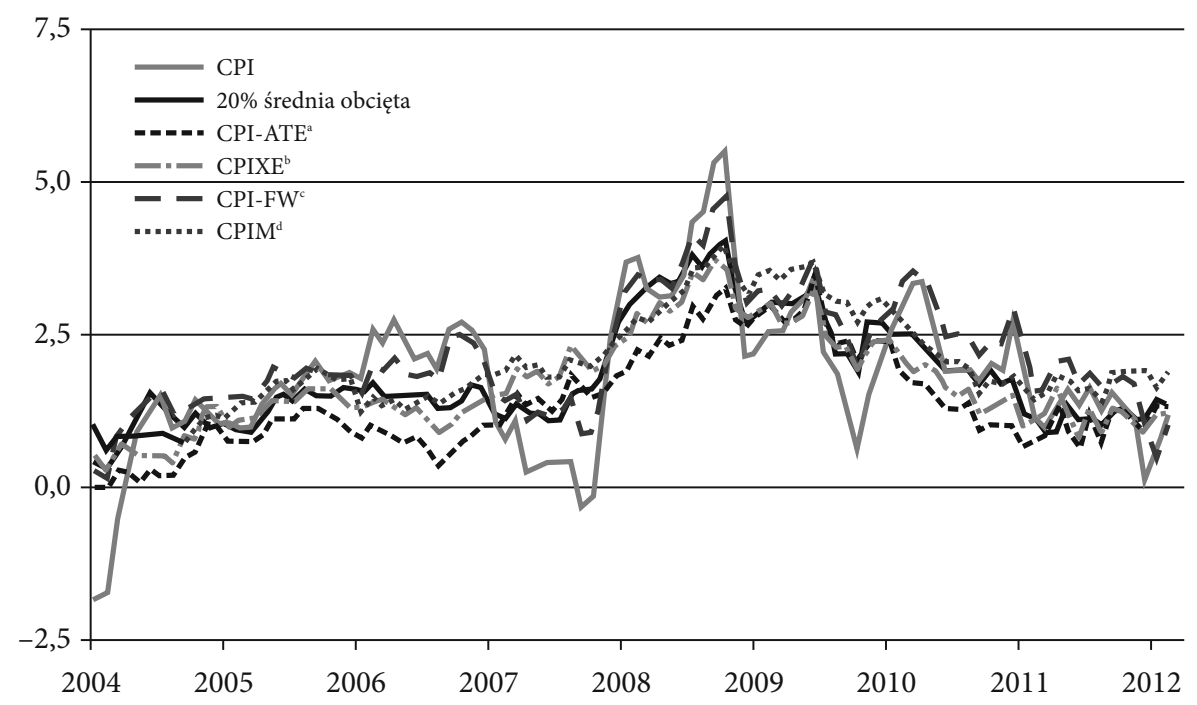

a Wskaźnik skorygowany o zmiany podatków i z pominięciem produktów energetycznych.

${ }^{\mathrm{b}}$ Wskaźnik skorygowany o zmiany podatków i z pominięciem krótkotrwałych zmian cen energii.

c Wskaźnik skorygowany o sezonowość zmian cen.

d Wskaźnik oparty o model inflacji bazowej.

Źródło: Norges Bank, Monetary Policy Report 1/2012, Central Bank of Norway, Oslo 2012, s. 12, http://www. norges-bank.no/pages/88292/MPR_1_12.pdf (01.091.2012).

W marcu i kwietniu 2008 roku największe banki w USA (w tym Citigroup, Merrill Lynch, Goldman Sachs, Morgan Stanley, Lehman Brothers) zostały dokapitalizowane środkami z rezerw walutowych w celu zapobieżeniu upadłości. Działania te przyniosły tylko krótkotrwałą poprawę. W kolejnych miesiącach zaufanie na rynku międzybankowym spadło w obawie przed niewypłacalnością kontrahentów. Wpływ na inflację miała też sytuacja wewnętrzna, wysoki popyt wewnętrzny oraz wzrost podstawowych stóp procentowych. W kwietniu zarząd Banku Norwegii podjął decyzję o podniesieniu głównej stopy procentowej o 0,25 p.p. z 5,25\% do 5,5\% ${ }^{13}$, a następnie o kolejne 0,25 p.p. na spotkaniu zarządu w czerwcu 2008 roku do rekordowego poziomu 5,75\%. Obie decyzje zostały spowodowane przede wszystkim rosnącym popytem wewnętrznym i inflacją, która rosła szybciej niż zakładano.

${ }_{13}$ Na podstawie statystyk Norges Banku, http://www.norges-bank.no/en/price-stability/monetary-policy-meetings/key-policy-rate/key-policy-rate-monetary-policy-meetings-and-changes-in-the-keypolicy-rate/ (01.09.2012). 
Zdecydowano się na taki krok, mimo rosnących premii za ryzyko na rynku i słabych danych gospodarczych z zagranicy.

Zgodnie z rysunkiem 3 Bank Norwegii spodziewał się dalszego wzrostu popytu wewnętrznego oraz inflacji w państwie w stopniu wyższym od poprzednich prognoz i to był główny motyw decyzji o podniesieniu stóp. $Z$ drugiej strony rysunek przedstawiał już też złe prognozy dotyczące wzrostu gospodarczego na świecie oraz rosnące premie za ryzyko. Sytuacja gwałtownie zmieniła się po bankructwie Lehman Brothers, ogłoszonym 15 września 2008 roku. Wtedy też norweska gospodarka została narażona na poważne wstrząsy. Rynki pieniężne okresowo przestały funkcjonować. Wskutek wysokich premii za ryzyko stopy na rynku pieniężnym wzrosły zdecydowanie ponad poziom głównej stopy procentowej. Doskonale prezentuje to rysunek 4 .

\section{Rysunek 4. Wysokość stóp procentowych w Norwegii w latach 2008-2012}

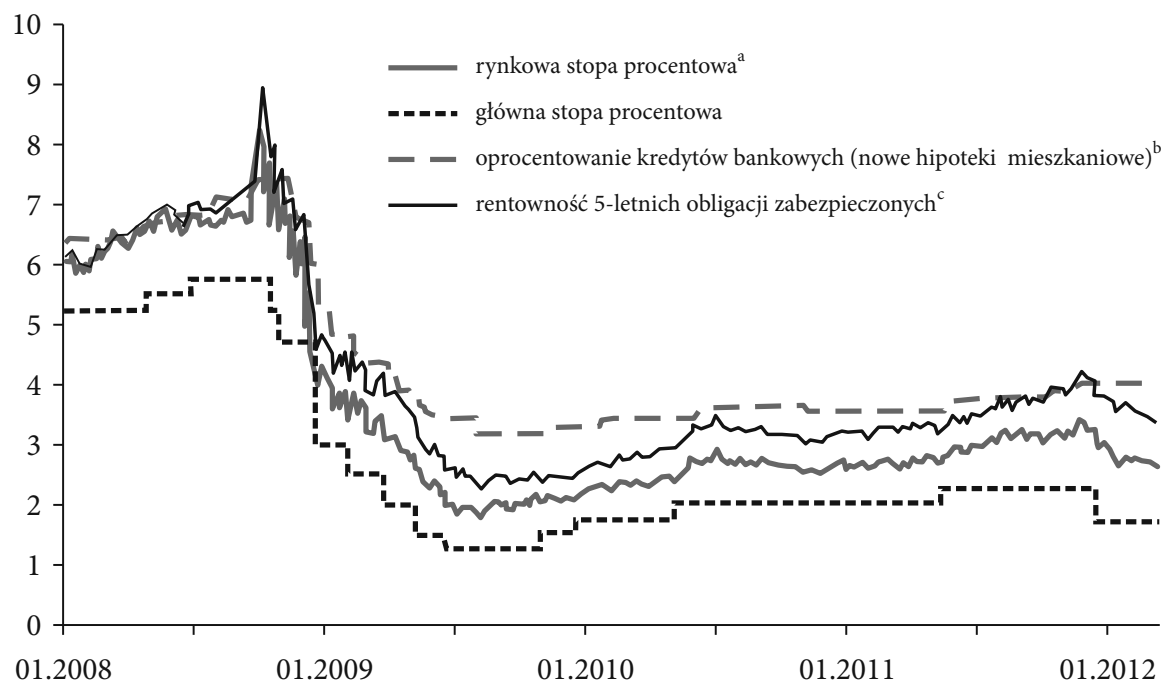

a 3-miesięczna stopa procentowa NIBOR (stopa procentowa kredytów oferowanych na rynku międzybankowym o terminie zapadalności od 1 tygodnia do 1 roku).

${ }^{\mathrm{b}}$ Oprocentowanie nowych kredytów hipotecznych o wartości 1 mln koron. Dane dla 20 największych banków, ważone udziałem w rynku.

c Suma 3-miesięcznej stopy NIBOR i orientacyjnych spreadów kredytowych na 5-letnie obligacje.

Źródło: Norges Bank Monetary Policy Report 1/2012, op.cit., s. 11.

Zjawisko to wynikało z przepływu premii za ryzyko z rynku globalnego do Norwegii. Banki podniosły swoje stopy kredytowe, ponieważ wzrosły koszty krótkookresowego i długoterminowego finansowania podaży gotówki. Instytucje finansowe stały się jeszcze bardziej niechętne do wzajemnego pożyczania sobie pieniędzy. Kanały kredytowe zawęziły się, a ceny akcji i surowców zaczęły gwałtownie spadać. 
Globalna gospodarka weszła w ostry kryzys, a niepewność sytuacji gospodarczej została spotęgowana. Stopniowo okazywało się jasne, że wpływ kryzysu finansowego na realną gospodarkę Norwegii może być poważny i długotrwały. Inflacja zwolniła, a kurs korony norweskiej zaczął gwałtownie spadać. Wynikało to ze zmniejszającej się gotowości do ryzyka na rynkach międzynarodowych, a korona norweska jako waluta peryferyjnego państwa uchodziła za mniej płynną.

Bardzo możliwe, że deprecjacji korony sprzyjał także spadek cen ropy naftowej i innych surowców. Kształtowanie kursu korony norweskiej wobec euro przedstawia rysunek 5 . Pod koniec roku kurs walutowy był wyraźnie niższy niż w poprzednich latach. Środki antykryzysowe wdrażane przez Bank Norwegii objęły kilka pól. Przede wszystkim zarząd banku dokonał rewizji stopy procentowej. Główna stopa procentowa została obniżona do końca roku o prawie połowę z 5,75\% do 3,00\% na koniec roku. Na posiedzeniu zarządu 15 października postanowiono o obniżce stopy z 5,75\% do 5,25\%. Na kolejnym posiedzeniu 29 października zdecydowano się na kolejną obniżkę o 0,50 p.p. Dnia 17 grudnia stopa procentowa została zmniejszona o kolejne 1,75 p.p., osiągając 3,00\%. Polityka obniżania stóp była kontynuowana do 2010 roku $^{14}$.

U podstaw decyzji o zdecydowanym obniżeniu głównej stopy procentowej leżały znacznie słabsze perspektywy popytu zarówno krajowego, jak i zewnętrznego. W listopadzie Międzynarodowy Fundusz Walutowy obniżył prognozy wzrostu gospodarczego w 2009 roku, co skłoniło wiele państw do obniżki stopy procentowej. Norwegia obserwowała spadek cen ropy naftowej oraz malejący optymizm gospodarstw domowych. Wysokie tempo obniżek stopy procentowej wynikało też z chęci uzyskania wyższej efektywności polityki pieniężnej, w obliczu presji ze strony wysokich premii za ryzyko ${ }^{15}$. Deprecjacja korony w 2008 roku mogła być również czynnikiem wzmacniającym inflację, co było dodatkowym bodźcem do obniżki. Pełen zakres czynników, który wpłynął na decyzję zarządu Banku Norwegii odnośnie do stopy procentowej w drugiej połowie roku 2008, przedstawiono na rysunku 6.

Poza obniżką głównej stopy procentowej Bank Norwegii postanowił wzmocnić płynność na rynku finansowym w celu obniżenia krótkookresowo stóp procentowych na rynku pieniężnym. Głównym narzędziem banku wpływającym na płynność są kredyty f-loans. Kredyty te udzielane są pod zastaw papierów wartościowych o stałej stopie procentowej i określonym terminie zapadalności.

14 Norges Bank Monetary Policy Report 3/2011, Norges Bank, Oslo 2011, s. 12, http://www.norgesbank.no/pages/87120/MPR_3_11.pdf (01.09.2012).

15 Premia za ryzyko rozumiana jako różnica między stopami rynkowymi i główną stopą procentową. 
Rysunek 5. Kurs wymiany NOK/EUR w latach 2005-2012

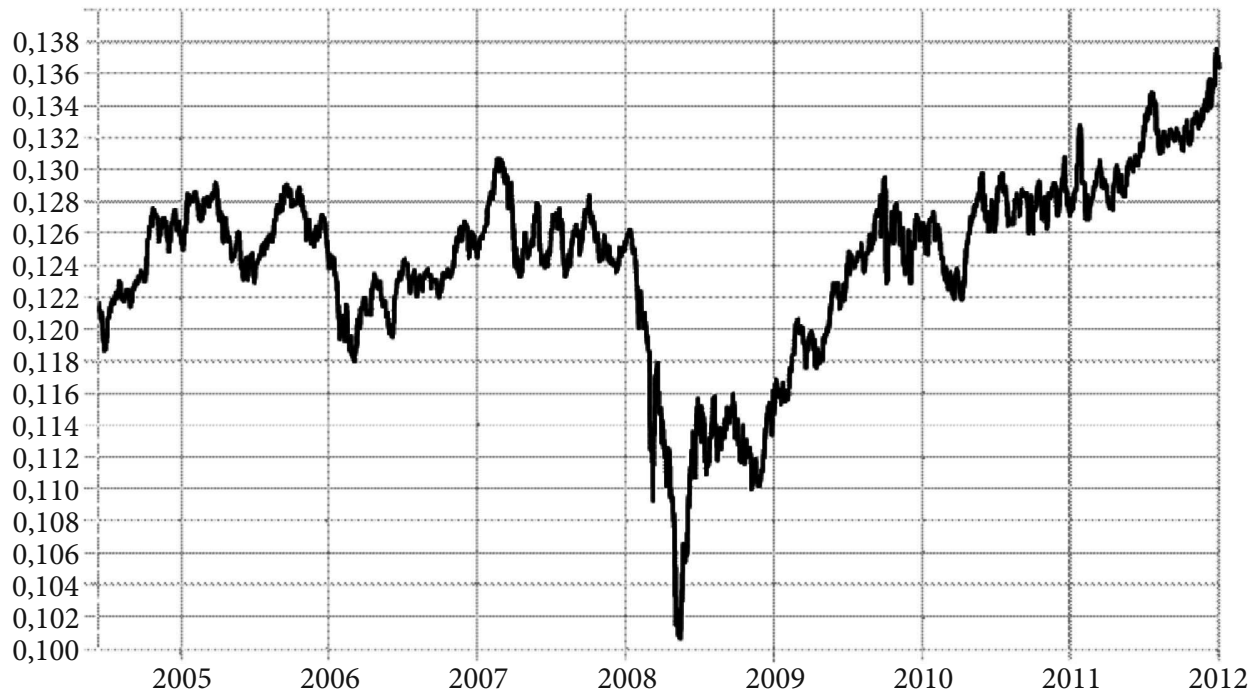

Źródło: Na podstawie danych EBC, http://www.ecb.int/stats/exchange/ eurofxref/html/eurofxref-graph-nokołoen.html (01.09.2012).

Zapadalność f-loans będzie się różnić w zależności od sytuacji płynności w systemie bankowym. Stopy procentowe f-loans ustalane są w drodze licytacji. Bank Norwegii ustala łączną kwotę kredytów. Płynność banków została zwiększona dzięki ułatwieniom w uzyskiwaniu kredytów (np. dodatkowym 2 aukcjom tych kredytów 15 września 2008 roku, $\mathrm{z}$ terminem zapadalności dwa $\mathrm{dni}^{\mathrm{i}}{ }^{16}$ ), a także wprowadzeniu kredytów o dłuższych terminach zapadalności (2-letnich). Ponieważ ceny na norweskim rynku zależą od dostępności pożyczek w dolarach amerykańskich, Bank Norwegii udostępnił bankom pożyczki w tej walucie jako rekompensatę niskiej podaży dol. na rynku. Ponadto poszerzona została specjalna linia swapowa w amerykańskiej Rezerwie Federalnej w wysokości do 15 mld dol., która dała bankowi większą swobodę w działaniach zapobiegających kryzysowi. Linia ta obowiązywała już wcześniej i miała wartość do 5 mld dolarów, natomiast na czas najgłębszego kryzysu została zwiększona do 15 mld dolarów do 30 kwietnia 2009 roku. Zagraniczne banki niemające dostępu do kredytów f-loans zyskały możliwość pożyczania norweskiej waluty bezpośrednio z banku centralnego dzięki swapom walutowych ( $f x$ swaps). $\mathrm{W}$ umowach swapowych bank udzielał kredytów zabezpieczonych w innej walucie, np. pożyczek w koronach zabezpieczonych dolarami.

16 S.A. Berg, Banks' liquidity situation during the financial turmoil in autumn 2008, „Norges Bank Economic Bulletin” 2012, Vol. 83, s. 1, http://www.norges-bank.no/pages/87616/Banks\%E2\%80\%99_ liquidity_situation_Autumn2008.pdf (01.09.2012). 


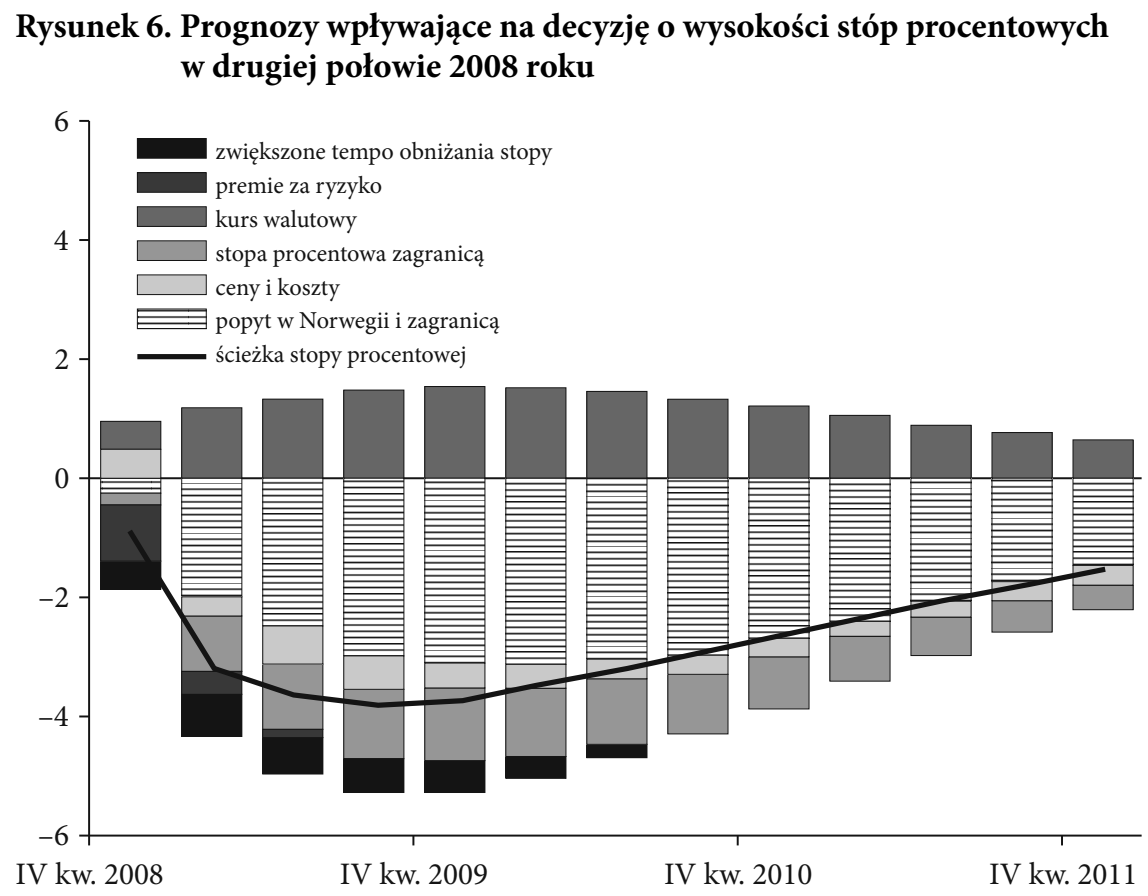

Źródło: Norges Bank Annual Report 2008, Norges Bank, Oslo 2009, s. 65, http://www.norges-bank.no/ Upload/74571/EN/Annual_Report_2008.pdf (01.09.2012).

Również norweski parlament w porozumieniu z Ministerstwem Finansów przyjął pakiet środków, w ramach którego banki zyskały możliwość wymiany niepłynnych papierów wartościowych zabezpieczonych hipoteką na bardzo płynne obligacje rządowe. Okres zapadalności został tu ustalony na trzy lata, a w 2009 roku został powiększony do pięciu lat. Łączna pula tych specjalnych umów swapowych (OMF) osiągnęła 350 mld koron. Bank Norwegii został podmiotem administrującym tym mechanizmem, który zapewnił bankom dostęp do długoterminowego finansowania w okresie, kiedy rynki obligacji nie działały normalnie. Jednym z mechanizmów pozwalających na kontrolowanie sytuacji w największych bankach Norwegii oraz ich potrzeb w zakresie płynności są w Norwegii regularne ankiety przeprowadzane w pięciu największych bankach kraju oraz banku Nordea ${ }^{17}$. Jesienią 2008 roku dane z banków zbierano kilkakrotnie i aż dwukrotnie w ciągu miesiąca w listopadzie i grudniu. Zgodnie $\mathrm{z}$ wynikami ankiet bank centralny wiedział, że w okresie sierpień-październik wzrosły finansowe potrzeby banków o charakterze krótkookresowym

17 Pięć największych banków Norwegii to: DNB, Sparebank 1 SR-Bank, Sparebank 1 Nord-Norge, Sparebank 1 SMN i Sparebanken Vest. 
(o horyzoncie czasowym do roku), ale już w grudniu bardzo krótkoterminowe potrzeby finansowe (do miesiąca) straciły na znaczeniu ${ }^{18}$. Dzięki takim danym bank mógł szybko i skutecznie umożliwić płynność na rynku. Rysunek 7 przedstawia zmiany wielkości płynności strukturalnej będącej całkowitą wartością wkładów a vista w Banku Norwegii oraz nadwyżki płynności rozumiane jako depozyty typu overnight. Nadwyżki płynności są utrzymywane w celu obniżenia krótkoterminowych stóp procentowych na rynku do poziomu zbliżonego z wartością głównej stopy procentowej.

\section{Rysunek 7. Nadwyżka płynności i płynność strukturalna} na rynku pieniężnym (w mld koron, lata 2004-2010)

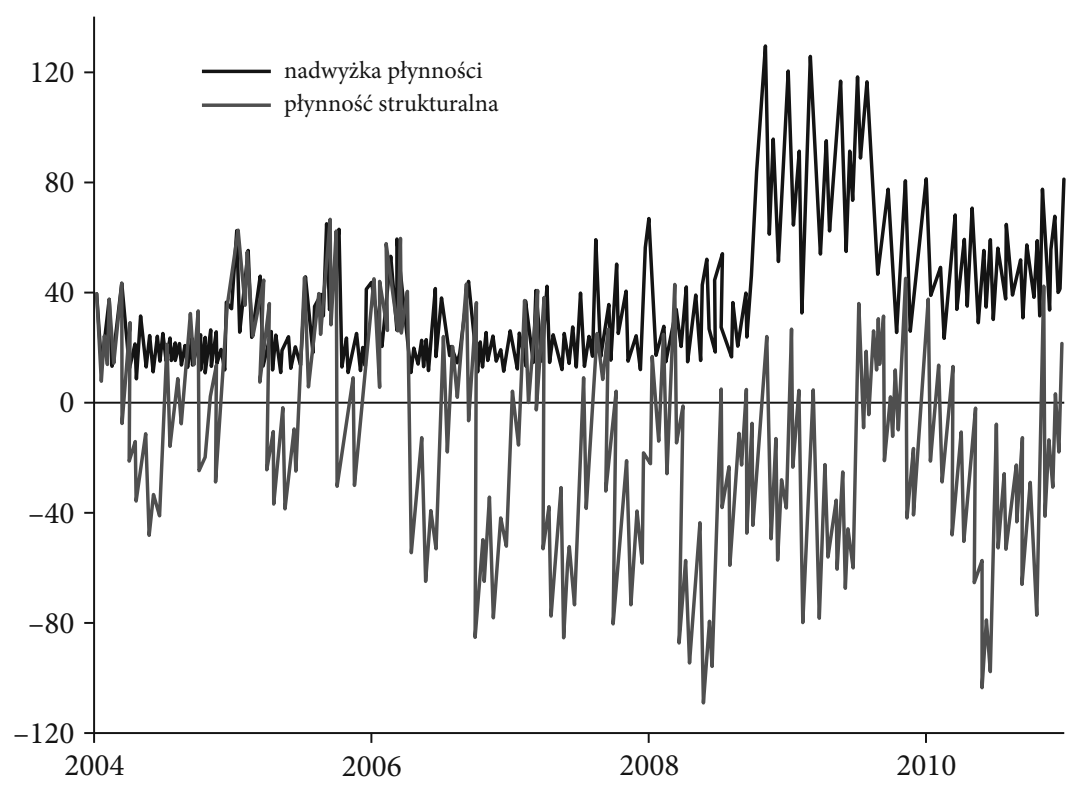

Źródło: Norges Bank Annual Report 2010, Norges Bank, Oslo 2011, s. 108, http://www.norges-bank.no/ Upload/82632/AnnualReport2010.pdf (01.09.2012).

W warunkach normalnych nadwyżka rzędu 20-30 mld koron wystarczała do osiągnięcia tego celu, jednak w wyniku kryzysu wartość ta okazała się niewystarczająca ${ }^{19}$. Rysunek 7 pokazuje, że po roku 2008 wzrosła wartość nadwyżek płynności, co z pewnością miało przełożenie na spadek krótkookresowych stóp procentowych

18 S.A. Berg, op.cit., s. 3.

19 Norges Bank Annual Report 2010, Norges Bank, Oslo 2011, s. 107, http://www.norges-bank.no/ Upload/82632/AnnualReport2010.pdf (01.09.2012). 
na rynku pieniężnym. Rok 2008 był zdecydowanie najtrudniejszy i najważniejszy w zarządzaniu polityką monetarną Norwegii, gdyż to właśnie wówczas sektor bankowy przeżywał największe trudności.

Norweski sektor bankowy w dużej mierze zdominowany przez rodzime banki dobrze poradził sobie z pierwszą falą kryzysu, a podjęte przez Bank Norwegii środki zaradcze pozwoliły ochronić sektor bankowy przed problemami obserwowanymi w innych państwach na świecie. Gwałtowne spowolnienie gospodarcze na świecie wywołało jednak sporo konsekwencji poza sektorem bankowym. W Norwegii rok 2008 kończył się prognozami spowolnienia wzrostu gospodarczego, spadków produkcji, eksportu, spadków cen ropy naftowej i innych surowców. Kurs korony norweskiej gwałtownie spadł, łagodząc skutki kryzysu dla Norwegii. Spodziewano się również spadku zatrudnienia i inflacji, która ustabilizowała się wokół celu inflacyjnego, co zwiastowało obniżkę stóp procentowych.

\section{Działania Banku Norwegii w latach 2009-2010}

Rok 2009 był z jednej strony jedynym rokiem recesji w Norwegii w ostatnim czasie, $\mathrm{z}$ drugiej zaś był to już rok stabilizacji po zawirowaniach w sektorze bankowym w roku 2008. W zakresie polityki głównej stopy procentowej duże znaczenie już na początku roku miało obniżenie oczekiwań w stosunku do kształtowania się popytu i wzrostu gospodarczego w krótkim terminie. Jak pokazuje rysunek 8, Bank Norwegii zakładał spadek popytu, produktywności, pensji oraz cen przez cały rok 2009. Spodziewano się również spadku wartości korony i zagranicznych stóp procentowych. W związku z tym zdecydowano po raz kolejny obniżyć główną stopę procentową o 0,5 p.p. do poziomu 2,50\%. W marcu na kolejnym posiedzeniu zarządu banku uznano, że gospodarka norweska znajduje się w samym środku głębokiej recesji i obniżono oprocentowanie o kolejne 0,5 p.p. do $2 \%$. Działanie to powtórzono, na spotkaniu w maju obniżono oprocentowanie o kolejne 0,5\%, a w czerwcu - o 0,25 p.p. do poziomu 1,25\%. Gospodarka powoli zaczęła radzić sobie z kryzysem. W pierwszej połowie 2009 roku bezrobocie wzrosło mniej niż zakładano, ceny nieruchomości i akcji wzrosły, poprawiła się dostępność kredytów dla gospodarstw domowych. W tym samym czasie obserwowano spadek inwestycji w sektorze przedsiębiorstw. Inwestycje w ropę naftową pozostały na stabilnym poziomie. Na posiedzeniu zarządu 12 sierpnia 2009 roku uznano, że zmiany nie mają pewnego charakteru, a napływające dane mogą zmienić obraz na gorszy. Zadecydowano wówczas o niezmienianiu poziomu stóp procentowych. W październiku 2009 roku wzrost produkcji 
i zatrudnienia był już jednak wyraźny, cena ropy naftowej podnosiła się, podobnie jak wydatki publiczne i popyt gospodarstw domowych. Dnia 28 października 2009 roku podjęto decyzję o stopniowym zwiększaniu stopy procentowej, przez co Norwegia stała się pierwszym państwem w Europie, które zdecydowało się na ten krok po 2008 roku. W grudniu stopa procentowa osiągnęła poziom 1,75\%.

\section{Rysunek 8. Zmiany prognoz dotyczących czynników wpływających na decyzje o wysokości głównej stopy procentowej dotyczące okresu grudzień 2008 - marzec 2009}

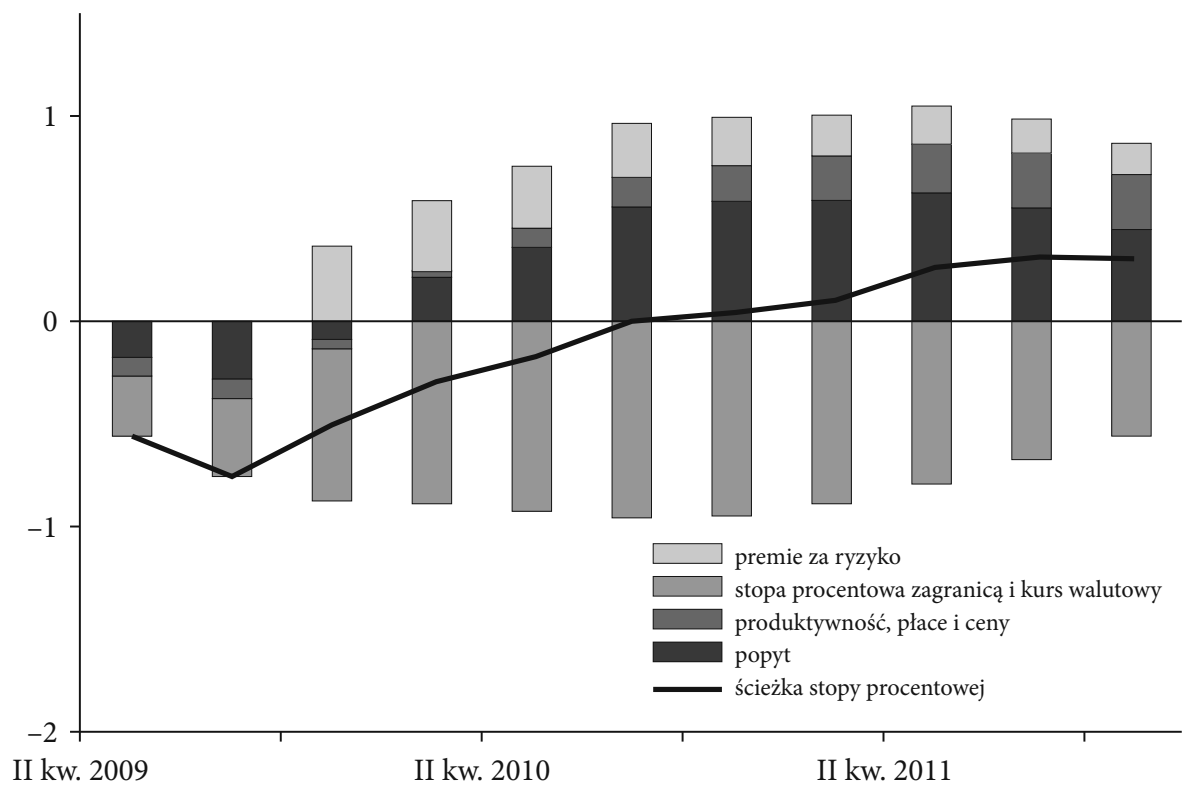

Źródło: Norges Bank Annual Report 2009, Norges Bank, Oslo 2010, s. 85, http://www.norges-bank.no/ Upload/78508/EN/Norges_Bank_Annual_Report_2009.pdf (01.09.2012).

W zakresie polityki płynnościowej rok 2009 był czasem powolnej normalizacji sytuacji w sektorze bankowym. W przeciągu roku Bank Norwegii rozpoczął proces ograniczania podaży płynności podniesionej w roku 2008 i wycofywania się z nadzwyczajnych środków podjętych w czasie największego kryzysu. W wyniku turbulencji na rynkach finansowych na początku 2009 roku popyt na dolary amerykańskie był ciągle wysoki i trudno było uzyskać kredyty w tej walucie o dłuższych terminach zapadalności. Jednak dzięki umowie kredytowej Banku Norwegii z amerykańską Rezerwą Federalną z jesieni 2008 roku bank miał możliwość zapewnić płynność norweskim bankom. W przeciągu roku stopy procentowe na rynku dolara zaczęly jednak spadać, a bank centralny zaczął rezygnować z nadzwyczajnych instrumentów. 
W celu utrzymania rynkowych stóp procentowych na rynku korony norweskiej na poziomie zbliżonym do głównej stopy procentowej zdecydowano się utrzymać podaż płynności w koronach na poziomie znacznie wyższym niż normalnie. Na początku 2009 roku depozyty banków na rachunkach a vista w Banku Norwegii przekroczyły 100 mld koron. Wysoki poziom depozytów utrzymywał się w pierwszej połowie 2009 roku, ale potem stopniowo malał.

Ponadto bank dokonał kolejnej aukcji kredytów f-loans w lutym 2009 roku z dłuższym terminem zapadalności. W sumie w latach 2008 i 2009 banki pożyczyły w ten sposób ponad 35 mld koron. W 2009 roku rozpoczęto również podniesienie stóp w specjalnych umowach swapowych (OMF), gdyż na rynku wzrosła możliwość długoterminowego finansowania banków. Mechanizm OMF został całkowicie wygaszony w grudniu 2009 roku. Trzy razy w ciągu roku umożliwiono również płynność rynku dzięki swapom walutowym ( $f x$ swaps). Płynność w koronach była dostarczona w stosunku do dolarów. Dwukrotnie kredyty miały termin zapadalności po trzech miesiącach, a raz po miesiącu. Relatywnie dobra sytuacja Norwegii w 2009 roku sprawiła, że zaangażowała się ona w pomoc za granicą. W lipcu Bank Norwegii wraz z bankami centralnymi Szwecji, Finlandii i Danii podpisał umowy kredytowe dla islandzkiego Seðlabanki Islands o wartości 1,775 mld euro (norweski udział wyniósł 480 mln euro $)^{20}$. W 2009 roku Bank Norwegii podpisał również umowę kredytową z Międzynarodowym Funduszem Walutowym. Zgodnie z umową Bank Norwegii zapewnia MFW instrument finansowania zewnętrznego o wartości do 3 mld SDR lub do 30 mld koron. Umowa kredytu jest ważna przez 5 lat.

W roku 2010 gospodarka norweska powróciła na ścieżkę wzrostu gospodarczego. Inflacja była niższa od oczekiwanej i spadała, a chęć utrzymania wskaźnika CPI na poziomie około $2,5 \%$ oraz ustabilizowania wzrostu i zatrudnienia sugerowały utrzymywanie niskiego poziomu stóp. Na świecie jednak kryzys finansowy zaczął wchodzić w nową fazę. Koszty związane z ratowaniem systemów bankowych w połączeniu ze spadkiem dochodów z tytułu podatków i wzrostem wydatków społecznych doprowadziły do problemów $\mathrm{z}$ deficytami fiskalnymi i do wzrostu długu publicznego w wielu państwach na niebezpiecznym poziomie. Koszty zewnętrznego finansowania zadłużenia zaczęły gwałtownie rosnąć, podobnie jak bezrobocie. Trudna sytuacja za granicą wpłynęła również na gospodarkę Norwegii.

W odniesieniu do polityki głównej stopy procentowej Bank Norwegii przewidywał wzrost stopy w pierwszej połowie roku do około $2 \%$ i 2,5\% - w drugiej. W praktyce stopa procentowa została podniesiona na posiedzeniu zarządu banku w maju

${ }^{20}$ Na podstawie informacji Banku Norwegii, http://www.norges-bank.no/en/om/publisert/ pressemeldinger/2009/pressemelding-1-juli-2009/ (07.09.2012). 
do poziomu 2\%, później jednak nie dokonano już żadnych zmian w jej wysokości do końca roku. Wynikało to z słabszych od przewidywanych wyników gospodarki norweskiej, a także niższej inflacji. Zmiany oczekiwań co do zmiennych wpływających na decyzję o wysokości stopy procentowej przedstawiono na rysunku 9. Pokazuje on, że w przeciągu całego roku większość danych była gorsza od oczekiwań. Oczekiwania co do stóp procentowych za granicą spadały przez cały rok. Perspektywy niższych stóp za granicą mogły zwiastować $\mathrm{z}$ kolei większe różnice między stopami w kraju i za granicą i mogły doprowadzić do umocnienia korony, niższej inflacji i spadku produkcji. Sytuacja gospodarki wewnętrznej była gorsza od prognoz z poprzedniego roku, głównie przez spadki w sektorze naftowym, niższy od oczekiwanego eksport oraz słaby popyt gospodarstw domowych. Inflacja bazowa w 2010 roku była słabsza niż przewidywano. Zewnętrzne impulsy cenowe były słabe, a wzrost cen towarów i usług wyprodukowanych w kraju obniżył się w wyniku spadających wynagrodzeń i wzrostu produktywności. Wszystko to obniżyło prognozy głównej stopy procentowej o prawie 1 p.p.

W zakresie polityki płynnościowej Bank Norwegii w 2010 roku musiał utrzymywać wysoki poziom płynności w systemie bankowym przez cały rok 2010. Stopy dotyczące dłuższych okresów czasowych wciąż wyższe były w Norwegii niż w innych państwach. By zachęcić banki do większej aktywności na rynku pieniężnym, w grudniu zarząd wprowadził zmiany w zarządzaniu polityką płynności poprawką do rozporządzenia w sprawie dostępu banków depozytów i kredytów w Banku Norwegii (Forskrift om bankers adgang til lån og innskudd i Norges Bank mv) ${ }^{21}$. Zgodnie z nią tylko pewna część depozytów bankowych będzie oprocentowana zgodnie z główną stopą procentową. Depozyty przekraczające określoną wielkość będą oprocentowane zgodnie z niższą stopą procentową. W 2010 roku średnia płynność strukturalna wyniosła 25 mld koron. Bank Norwegii zapewniał ją za pomocą zwykłych kredytów o stałym oprocentowaniu (f-loans), zwiększając całkowitą płynność w systemie bankowym do 47 mld koron. W roku 2010 odbyły się 42 aukcje na kredyty f-loans. W listopadzie 2010 roku nadszedł okres zapadalności kredytu dwuletniego z roku 2008 o łącznej wartości 12,6 mld koron, co nie miało żadnego wpływu na wysokość stóp. W 2010 roku przypadł też okres zapadalności umów swapowych (OMF) o wartości 13 mld koron ${ }^{22}$.

\footnotetext{
21 Więcej zob. Norges Bank, http://www.norgesbank.no/en/prisstabilitet/ likviditetsstyring/likviditetsstyringssystemet/endring-i-forskrift-om-bankers-adgang-til-lan-og-innskudd-i-norges-bank-mv-/ (01.09.2012).

22 Norges Bank Annual Report 2010, op.cit., s. 107.
} 


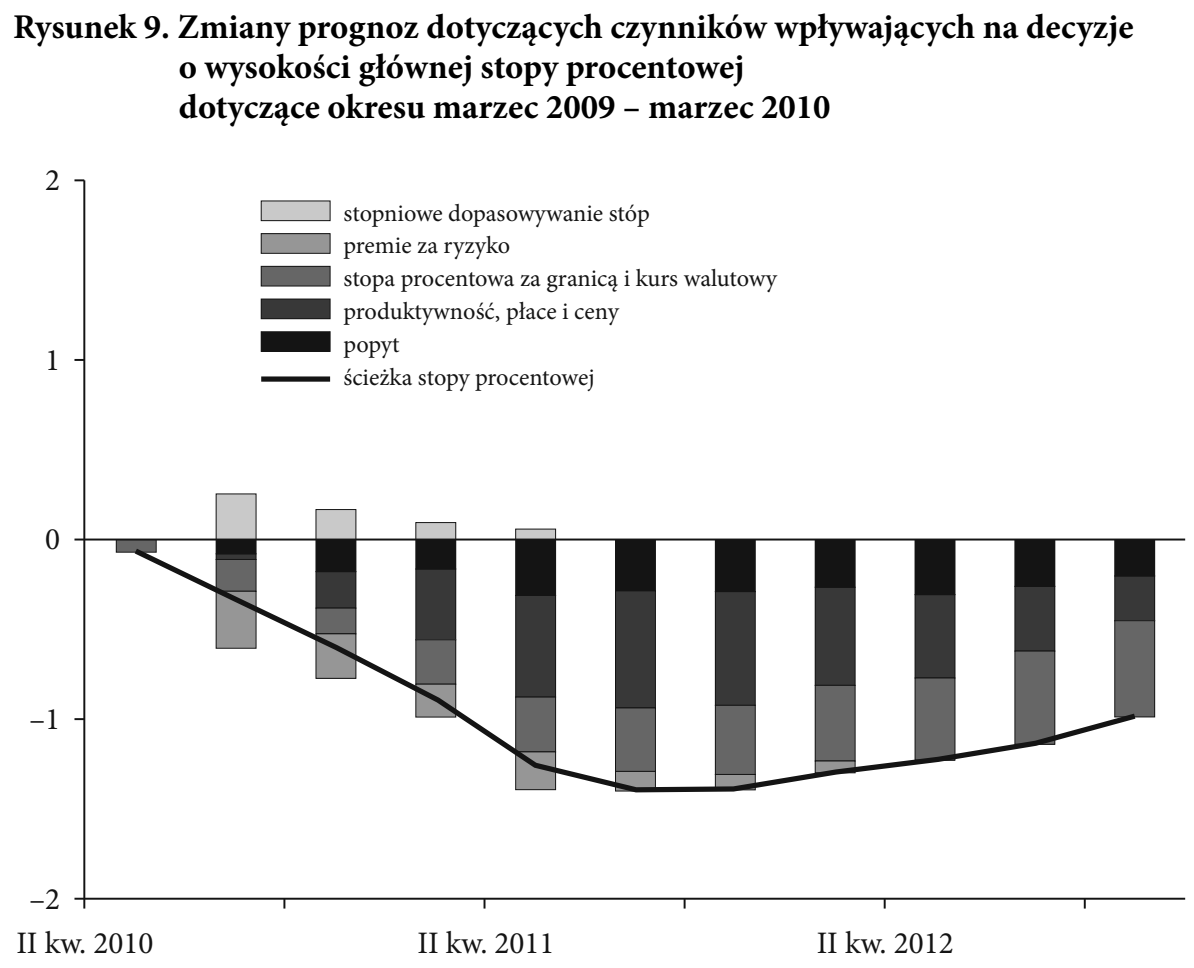

Źródło: Norges Bank Annual Report 2010, op.cit., s. 106.

\section{Działania Banku Norwegii w latach 2011-2012}

Po 2010 roku wraz z ustabilizowaniem gospodarki z norweskiego punktu widzenia zmalały wyzwania wobec polityki monetarnej. Na posiedzeniu zarządu w marcu 2011 roku zdecydowano o utrzymaniu głównej stopy procentowej na poziomie $2 \%$. Gospodarka Norwegii powracała do stanu równowagi szybciej niż zakładano. Tempo wzrostu imigracji powróciło do poziomu sprzed kryzysu. Norweskie terms of trade wzrosło dzięki podniesieniu się cen surowców i spadkami cen dóbr importowanych. Niska inflacja bazowa na poziomie $1,25 \%$ i silny kurs korony w połączeniu z perspektywą utrzymania się niskiej inflacji, a także brak silnej reakcji popytu na niskie stopy procentowe nie dawały podstaw do zmian głównej stopy. W czerwcu 2011 roku podjęto decyzję o podniesieniu stopy procentowej do 2,25\%. Rosnąca niepewność na rynkach zagranicznych spowodowana kryzysem zadłużeniowym w Europie zaczęła kontrastować z sytuacją w samej Norwegii, gdzie wzrost gospodarczy miał wynieść 
około $2 \%$. Wzrost wartości korony zaczął rodzić obawy o zbyt niską inflację. Jednocześnie spodziewano się wzrostu płac i cen w przyszłości, a przez to zakładano dalszy wzrost głównej stopy procentowej. Pod koniec roku sytuacja w gospodarce uległa pogorszeniu, a niepewność związana z kryzysem w Europie wzrosła. W obliczu niższych od przewidywanych danych na temat konsumpcji gospodarstw domowych w Norwegii i inflacji, która wciąż utrzymywała się na niskim poziomie, utrzymano stopę na niezmienionym poziomie i zaczęto przewidywać jej obniżenie w 2012 roku.

Rok 2012 to czas dalszego obniżenia stopy procentowej. W kwietniu jej wysokość zredukowano do 1,50\% i poziom ten utrzymał się do października. Niska stopa procentowa w 2012 roku wynika z rosnących obaw o kolejną recesję, które ujawniły się na początku roku, wysokich premii za ryzyko, a więc dużej różnicy między główną stopą procentową a stopami rynkowymi. Silna korona zaczęła wpływać negatywnie na eksport. Inflacja utrzymuje się na niskim poziomie $1,25-1,50 \%$. Wysoki poziom niepewności ogranicza konsumpcję. Bank centralny w swoich prognozach zakłada jednak możliwość wzrostu stopy procentowej do 3-4\% do roku 2015 wraz z poprawą sytuacji na rynku. W październiku na posiedzeniu zarządu zwrócono szczególną uwagę na złą sytuację gospodarczą norweskich partnerów handlowych. Kurs korony wzrósł do poziomu wyższego niż zakładano, a wcześniejsza obniżka stóp wpłynęła na obniżenie tempa tego wzrostu. Całoroczna inflacja ma osiągnąć poziom 1-1,5\%, a ogólna sytuacja gospodarcza kraju jest dobra. Inwestycje i konsumpcja rosną, na rynku nieruchomości obserwuje się boom, który może doprowadzić do podniesienia stóp w 2013 roku $^{23}$.

\section{Podsumowanie}

Konkludując, Bank Norwegii poprzez skuteczną politykę przyczynił się do złagodzenia skutków globalnego kryzysu gospodarczego w Norwegii i szybkiego wyjścia państwa $\mathrm{z}$ recesji. Odporność norweskiej gospodarki na kryzys jest w dużej mierze wynikiem skutecznego zarządzania makroekonomicznego w polityce monetarnej. Polityka ta odegrała szczególną rolę w latach 2008 i 2009, gdy poziom niepewności na rynku był najwyższy, a wysokość głównej stopy procentowej zmieniała się bardzo gwałtownie. Dzięki trafnym decyzjom Norwegia była pierwszym państwem w Europie, które po upadku banku Lehman Brothers mogło podnieść stopę

${ }_{23}$ Norges Bank Monetary Policy Report 3/2012, Norges Bank, Oslo 2012, s. 7, http://www.norges-bank. no/pages/91224/MPR_312_k.pdf (16.11.2012). 
procentową ze względu na szybką poprawę sytuacji w gospodarce wewnętrznej. Ogromnym wyzwaniem dla banku centralnego było też zarządzanie rezerwami walutowymi pochodzącymi z sektora naftowego. Choć straty związane z załamaniem na rynku akcji i obligacji były gigantyczne, to dywersyfikacja portfolio inwestycyjnego okazała się czynnikiem zmniejszającym ryzyko, a system lokowania nadwyżek finansowych okazał się stabilny mimo krótkookresowych trudności. Środki akumulowane przez bank centralny pozwoliły na zwiększenie wydatków fiskalnych bez negatywnego wpływu na długofalową wartość aktywów funduszu emerytalnego. W roku 2012 sytuacja gospodarcza Norwegii jest relatywnie dobra, choć niepewność w Europie i boom na norweskim rynku nieruchomości mogą być czynnikami destabilizującymi sytuację w gospodarce.

\section{Actions of Central Bank of Norway during 2007+ economic crisis}

The period of global economic crisis starting from 2008 is a great challenge for public institutions responsible for macroeconomic management. Although Norway is a country that has not been significantly affected by the crisis, the pace and scale of countercyclical actions were a major challenge for Norwegian institutions. The activities of the Norwegian central bank included interest rate policy, liquidity management on the interbank market and supervision of the oil fund. The policy of interest rates had a huge importance in 2008 when the bank made a few decisions under conditions of high uncertainty and unprecedented scale. The initial phase of the crisis was also crucial in terms of liquidity and policy of enhancing stability of Norwegian banks. Due to high fluctuations of prices on stock, bond and real estate markets it was also extremely difficult to manage the oil fund portfolio. Nevertheless, through effective policy the Bank of Norway has contributed to minimizing the crisis' costs.

\section{La Banque Centrale de Norvège au cours de la crise économique de 2007+}

La période de la crise économique à partir de 2008 jusquà ce jour est un grand défi pour les institutions chargées de la gestion macro-économique. Bien que la Norvège soit un pays où la crise n'a pas sensiblement affecté le fonctionnement de l'économie et son évolution a été relativement faible, les mesures anticycliques adoptées, leur rythme et leur ampleur ont constitué un défi majeur pour les 
institutions publiques. Les mesures prises par la Banque comprenaient la politique des taux d'intérêt, la gestion de la liquidité sur le marché interbancaire et le contrôle sur le Fonds pétrolier norvégien. Lévolution des taux d'intérêt était particulièrement importante en 2008, lorsque la Banque a pris la décision dans des conditions d'une grande incertitude. Dans la phase initiale de la crise, c'est la gestion de la liquidité visant à assurer la stabilité des banques norvégiennes, qui a joué également un rôle clé. En raison des fluctutions très importantes des prix des actions, des obligations et de l'immobilier, la gestion du portefeuille du Fonds pétrolier a également constitué un défi majeur. Grâce à sa politique efficace, la Banque de Norvège a contribué à réduire les coûts de la crise. 